\title{
RESENHA
}

\section{O PAPEL DE PAREDE AMARELO: UM CONTO SOBRE SAÚDE MENTAL DE MULHERES}

\section{Cristina Vianna Moreira dos Santos ${ }^{1}$}

"O papel de parede amarelo", conto de Charlotte Perkins Gilman, tem um valor estimado para além do campo literário. Originalmente publicado em 1892, sua versão em português, da Editora José Olympio, é de 2018. Redescoberta pelo feminismo norteamericano na década de 1970, a obra foi considerada um clássico da literatura feminista, e é um livro raro de uma escritora do século XIX sobre política sexual.

A história gira em torno do adoecimento, um tipo de fadiga mental, vivido pela protagonista, mulher branca, de classe média, letrada, tratada pelo marido que é médico renomado. Estes marcadores localizados nas experiências de gênero, raça e classe social, produzem uma protagonista adequada ao perfil da mulher como sujeito político do feminismo branco. Nesta obra, o caráter autobiográfico se faz presente, e o principal marcador que pode aproximar as experiências de mulheres das vivências da personagem deste conto, é sua condição emocional.

A narradora relata seu sofrimento psíquico e o tratamento imposto pelo marido, vividos nas experiências de conjugalidade e de maternidade, e intensamente, ressignificados a partir de sua relação com o papel de parede do quarto de criança da casa provisória. A história permite refletir sobre o lugar da mulher como sujeito político e a experiência subjetiva engendrada nos processos de gênero.

O conto, nesta resenha, foi pensado de modo a compreender sua localização como uma produção feminista, e a debater o tema na perspectiva da saúde mental de mulheres. Com este intuito, pretende-se apresentar os elementos intraobra e discuti-los, a semelhança de uma autópsia psicológica, relacionando-os ao risco de suicídio para a personagem. A autópsia psicológica é uma avaliação retrospectiva, utilizada para a compreensão dos aspectos psicológicos de um caso de suicídio, que pode levantar dados

\footnotetext{
${ }^{1}$ Professora Adjunta do Curso de Psicologia da Universidade Federal do Tocantins (UFT) e Coordenadora do Grupo de Pesquisa Sexualidade, Corporalidades e Direitos - UFT. Email: cristina.vianna@uft.edu.br Vol. 01, N. 04, Out. - Dez., 2018 - www.revistas.unilab.edu.br/index.php/rebeh
} 
por meio de entrevistas com informantes, ou análise de documentos relevantes. Para esta análise utilizamos como documento, o próprio conto, que é o diário da protagonista, com o objetivo de realizar uma autópsia psicológica sobre o caso ficcional.

A saúde mental da heroína aparece relacionada a possíveis fatores de risco. A história de vida da personagem está permeada por conflitos identitários, relação conjugal onde predomina a desconfirmação e a desigualdade, tratamento do marido médico que suprime sua principal fonte de prazer - a escrita - combinados com prescrições de controle sobre seu estado mental e físico.

O sofrimento psíquico da protagonista, ao contrário do que prega o esposo, tem impacto muito negativo em sua vida e gravidade maior do que decidida por ele na história. A personagem do conto está profundamente angustiada, vivendo momentos de exaustão e tristeza, experimentando confusões internas que podem levar a "loucura".

A protagonista não tem nome. Podemos, apenas, identifica-la na relação com outras personagens: ela é esposa de John, cunhada de Jennie, e a babá de seu bebê se chama Mary. A não nomeação da protagonista traduz o silenciamento em torno da própria identidade e a posição ambivalente da sua experiência "feminina" - ela é uma mulher, e isso parece o bastante para concretar sua existência - ela está sempre em relação ao outro, se constrói, como mulher, a partir do olhar do outro.

A casa onde se passa a história não é segura para a heroína. Alugada por três meses, para seu descanso e recuperação da "questão dos nervos", a casa é uma construção do tipo mansão colonial, apresentada como um lugar maravilhoso, com um amplo jardim de caramanchões sombreados, com flores exuberantes, arbustos e árvores retorcidas, e vinhas com banquinhos. Entretanto, a mansão se assemelha também a uma casa assombrada - a personagem afirma que pode sentir algo estranho nela.

O quarto infantil, onde, a contragosto, ela fica acomodada com o esposo, tem janelas gradeadas. De início incomodada, ao longo da trama ela diz já não se importar com outros elementos do quarto. O que passa a importar é o papel de parede. O papel de parede amarelo começa a ocupar sua mente. E a desafiá-la constantemente. Ela afirma que há algo marcante no papel, e que somente ela pode decifrar.

A personagem está em sofrimento psíquico à beira de uma crise aguda. Ao longo de toda a história a personagem relata viver em exaustão. Tem a sensação que não vale a pena esforçar-se por nada, relata impaciência e afirma que chora por qualquer coisa. Ela

Vol. 01, N. 04, Out. - Dez., 2018 - www.revistas.unilab.edu.br/index.php/rebeh 
se diz contente pelo fato de sua condição clínica não ser considerada grave pelo marido. Ao mesmo tempo, afirma que é deprimente sofrer de "problemas dos nervos".

Relata tristeza de não cumprir "seus deveres" e sente-se convertida em um fardo. Conta que custa muito despender energia para fazer o que considera pouco: vestir-se, receber visitas e fazer encomendas. Passa muito tempo sozinha. Apesar do jardim convidativo, fica a maior parte do tempo deitada no quarto e este hábito, sugerido fortemente pelo marido, torna-se tarefa forçosa. Ela considera um hábito ruim, pois deita e não dorme, e afirma que ainda tem que mentir para o marido sobre seu sono e descanso.

O marido é um médico de renome que assegura que nada de grave lhe acomete. Trata-se, apenas, de uma depressão nervosa passageira - uma ligeira propensão a histeria. A personagem é considerada "doente dos nervos." A opinião do marido sobre a não gravidade do caso é reforçada pelo irmão da narradora, apresentado também como um médico de renome. $\mathrm{O}$ tratamento imposto pelo marido inclui óleo de fígado de bacalhau, cerveja, vinho e carne malpassada.

\footnotetext{
Assim, tomo fosfatos ou fosfitos - não sei ao certo -, e tônicos e ar fresco e dou caminhadas e faço exercícios e estou absolutamente proibida de "trabalhar" até me restabelecer. Em particular, discordo da opinião deles. Em particular, acredito que um trabalho adequado, com estímulos e variedades, iria me fazer bem (p. 13).
}

A personagem anseia por estímulo e atividade intelectual. O tratamento imposto pelo marido é, portanto, fonte importante de sua aflição. Ele também é infantilizado. O marido carrega a esposa no colo, coloca-a para deitar, e lê para ela até cansá-la. Ele afirma que a pior coisa que pode acontecer a heroína é pensar sobre sua condição. Ele ri dela e a chama de tolinha. Ela afirma que isso é de se esperar no casamento, revelando a estreiteza da vida privada, somada a ausência de vida pública.

A heroína reconhece que o fato de o marido ser seu médico faz com que ela não se recupere mais rápido. Como médico, ele é um homem da ciência que define e explica a experiência de outrem, e quando ela expressa desacordo sobre seu próprio quadro, ele, por meio de olhar severo e repreensivo, pede que nem por um momento ela pense na ideia de melhora, aguardando a submissão dela esperada. Sua racionalidade se opõe e subjuga a irracionalidade da chamada histeria, que é a estigmatização da doença mental de mulheres. Na apresentação do conto, afirma Marcia Tiburi:

Vol. 01, N. 04, Out. - Dez., 2018 - www.revistas.unilab.edu.br/index.php/rebeh 
A histeria como doença feminina é a ideologia do homem no contexto de uma evidente política sexual. Nesse contexto, a invalidez da mulher é um fator necessário para o bom funcionamento do controle a ser exercido sobre ela (p. 9).

Pensando em estratégias de instrumentalização e controle, o esposo, que detesta que ela escreva, insiste para ela não se entregue a devaneios, depreciando seu poder imaginativo e sua capacidade de produzir histórias. Em sua opinião escrever seria uma combinação muito negativa com sua "debilidade dos nervos", e resultaria em fantasias exaltadas. Segundo o marido, a paciente esposa deveria usar sua força de vontade, seu autocontrole e seu bom senso para dominar essa propensão.

A personagem permanece resistindo por meio da escrita. Ela conta que escrever é um alívio muito grande para sua mente e escreve um diário que nos revela sua reflexão sobre o sentido do seu sofrimento.

A relação conjugal é contraditória e desigual. A heroína experimenta ambivalência quando diz que John é querido, atencioso e amável, e que ele a adora, mas que sente uma raiva irracional dele. A raiva sentida é atribuída aos seus nervos, pois está certa de que não era tão sensível antes do adoecimento. À medida que a história se desenrola ela passa a relatar medo do marido, e diz que não gosta da expressão em seu olhar. Ele diz: "Pode ficar doente o quanto quiser!", mas a cura virá somente se ela cuidar de si mesma por amor a ele e manter-se saudável.

John não faz ideia do quanto realmente sofro. Ele sabe que não há razão para eu estar sofrendo e isto o satisfaz (p. 20).

A protagonista é uma mulher oprimida que pede ajuda. Ela expressa por mais de uma vez seu desejo de que o marido a leve embora da casa. O marido nega seu pedido e seu veredito é que a personagem está melhor, ainda que ela mesma não perceba. Ele ameaça que se ela não se recuperar do tratamento vai enviá-la para o psiquiatra Weir Mitchell - o pior médico que tratou a autora Charlotte de sua depressão. Neste ponto, fica explícito o caráter autobiográfico do conto.

Em torno da maternidade há o não-dito. O seu bebê não tem nome nem gênero e a personagem fala sobre ele apenas por duas vezes. A primeira é quando ela diz ter sorte, pois a babá é boa para o bebê, e revela que não pode estar com ele, pois acaba ficando 
muito nervosa. A segunda é quando ela diz que o que a consola é que o bebê está saudável e feliz, pois ela o poupou de estar no quarto infantil com o terrível papel de parede.

A estranheza do cenário gira em torno do papel de parede. Ele tem curvas imperfeitas e duvidosas que "cometem suicídio". Tem uma cor repulsiva e revoltante. Seu padrão tem a mesma forma repetida e seu subpadrão chega a ser irritante. Por ele saltam grandes ondas de horror ótico e desenhos grotescos. Surgem cabeças, olhos e fungos que brotam e crescem, infinitamente. Ele mancha tudo o que toca. O papel de parede é enfim, incompreensível e medonho. Curiosamente, ele também tem um cheiro. O cheiro é amarelo. Um cheiro que se espalha por toda a casa e penetra em seus cabelos. Um cheiro que ameaça sua integridade quando a coloca em situação de risco.

No início fiquei incomodada. Pensei seriamente em atear fogo à casa - para destruir o cheiro (p. 53).

Ao longo do conto, a protagonista vai interagindo intensamente com o papel. Ele "olha" para a personagem como se soubesse da influência que exerce sobre ela. Ela fica zangada com sua "impertinência e tenacidade". À noite, o papel sob qualquer luz, transforma-se em grades. A luz da lua aparece como algo invasivo que entra por uma janela ou por outra. Ela suspeita que o papel de parede se mexe.

Insone, a personagem passa boa parte da noite observando e estudando seus movimentos. Ela sente que o papel de parede se move em primeiro plano. E em segundo plano, há uma mulher aprisionada, inclinada para a frente rastejando. Parece que há muitas outras mulheres, mas, às vezes, é apenas uma que rasteja velozmente sacudindo o papel, tentando escapar em vão. Contraditoriamente, ela sabe que a mulher sai do papel durante o dia, porque a viu rastejando pelo jardim. Diz que só poderia ser ela, considerando que "a maior parte das mulheres não rasteja à luz do dia".

Sempre tranco a porta quando rastejo durante o dia (p. 58).

A personagem narradora, vivendo em exaustão, está à beira de um colapso. Lancemos um olhar sobre seu quadro clínico até o momento em que ela se identifica com um animal rastejante. Fatores estressores apontados a partir da história ficcional, podem ser discutidos como risco à sua saúde mental. No conto, o risco se expressa: na luta pela identidade; na relação conjugal contraditória, desigual e opressora; no silêncio em torno

Vol. 01, N. 04, Out. - Dez., 2018 -www.revistas.unilab.edu.br/index.php/rebeh 
da experiência conflituosa da maternidade; na estranheza da casa, lócus de amor e afeto, e também de confinamento e falta de autonomia da heroína; na suposta garantia do marido médico que nada de grave lhe acomete; na violência psicológica da desconfirmação de sua vivência subjetiva; no reconhecimento de que o marido sendo seu médico retarda sua recuperação. A protagonista está em sofrimento psíquico e pede ajuda.

A escrita, alívio para a angústia e espaço para a dor, pode ser lida como fator protetivo a sua saúde mental. A supressão da escrita, fonte de prazer e realização, também foi estressora para sua condição clínica, tratada como pouco importante. Mas esta condição foi se agravando, e o incômodo inicial que girava em torno do papel de parede, vai se transformando em estranheza e pensamento persistente sobre sua movimentação. A personagem passa a sofrer alucinações sensoriais, e sentimentos persecutórios e obsessivos pelo papel de parede amarelo.

A personagem conta que seu interesse pela vida foi se ampliando, à medida que o papel passou a fazer sentido para ela, e tornou-se algo em que ela pensar e com o que se preocupar. Paradoxalmente, seu sentido de vida se estreitou, à medida em que ela ficou atormentada com a tarefa de ter que vigiar as movimentações e mudanças do papel. Por fim, ela relata que a mulher do papel de parede tentava sair dele, e juntas, elas arrancaram metros de papel durante a madrugada.

Mas eu estou aqui e ninguém além de mim vai tocar nesse papel - não enquanto eu viver (p. 64).

É seu último dia na casa alugada, então os móveis foram retirados do quarto para voltarem ao lugar de origem. Os empregados foram embora. A heroína se tranca no quarto, deixando a chave no caminho de acesso à casa. Conta que quer surpreender o marido. Relata que tem uma corda, que nem mesmo a cunhada descobriu.

Mas agora estou bem atada à minha corda bem escondida (p. 67).

Uma autópsia psicológica visa reconstruir a vida psicológica de uma pessoa, analisando a saúde mental, os pensamentos, os sentimentos e os comportamentos precedentes a morte, a fim de compreender melhor as circunstâncias que contribuíram para o suicídio. Neste texto, discutimos o risco de suicídio para a personagem a partir de fatores clínicos e estressores presentes em sua história de vida. Dentre sentimentos

Vol. 01, N. 04, Out. - Dez., 2018 - www.revistas.unilab.edu.br/index.php/rebeh 
vivenciados pela protagonista que costumam estar presentes em quem pensa em se matar estão a depressão, a desesperança, o desamparo e o desespero. A investigação do risco de suicídio, leva em conta a presença destes afetos, somados a frases de alerta, a exemplo:

\footnotetext{
Tenho a impressão de que não vale a pena esforçar-me por nada, e estou ficando terrivelmente impaciente e lamuriosa. Choro por qualquer coisa, e a maior parte do tempo (p. 30).

Eis-me aqui, convertida num fardo! (p. 20).

É tão desanimador não ter ninguém para me dar conselhos ou acompanhar meu trabalho (p. 23).

Estou ficando tão zangada que cogito um ato desesperado (p. 66).
}

Entrelaçada ao destino da personagem está a vida da autora. História de vida e condição clínica de Gilman são apresentadas no posfácio de Elaine Hedges. Na infância, uma experiência estressora, que teve impacto muito negativo em sua vida, foi a separação de seus pais - seu pai abandonou a família. Na adolescência, Charlotte começou a refletir sobre as injustiças sofridas pelas mulheres. Em sua vida adulta, ela enfrentou o dilema que se apresentava a muitas mulheres do século XIX - o casamento ou a carreira.

Após o casamento, sentindo-se aprisionada ao papel tradicional feminino, começou a experimentar períodos de depressão, sentia fraqueza, insônia, incapacidade para trabalhar, cansaço constante e angústia. Sua disposição para a escrita era assolada por períodos de severa fadiga e letargia, contra as quais lutava constantemente. Gilman denunciou o tratamento médico inadequado que recebeu do renomado psiquiatra mencionado no conto. Ele suprimiu a escrita de sua rotina e limitou as horas de trabalho intelectual. Internada em um sanatório, ela relatou que neste período quase perdeu a sanidade. Sofreu pelo resto da vida as marcas do colapso nervoso vivenciado.

A autora foi uma das mais importantes escritoras feministas de seu tempo, professora e liderança que conduzia palestras sobre socialismo e liberdade para mulheres, e produzia diversas obras sobre sua situação sócio econômica. A partir do caráter autobiográfico da obra, nos aproximamos também da saúde mental da autora. Condições de risco foram se somando e se cruzaram em um mesmo desfecho para personagem e autora. O conto é uma aproximação sensível e tocante do sofrimento psíquico de uma mulher e de seus modos de resistência, denunciando, finalmente, que o patriarcado tem seu preço e tem feito as mulheres pagarem esta conta com culpa e com as próprias vidas.

\section{Referências}

Vol. 01, N. 04, Out. - Dez., 2018 - www.revistas.unilab.edu.br/index.php/rebeh 
GILMAN, C. P. O papel de parede amarelo. Rio de Janeiro: José Olympio, 2018.

Recebido em: 15/12/2018

Aceito em: 23/01/2019 